\title{
THE CONSTITUTIONAL PROBLEMS OF THE ALL-RUSSIAN VOTE
}

\author{
Svetlana N. Slobodchikova \\ Baikal State University, Irkutsk, Russian Federation
}

\begin{abstract}
Introduction: the compositional transformation of the domestic legal space requires the creation of clear forms for new constitutional and legal phenomena. The comparison of the all-Russian vote with the existing institutions of direct democracy contributes to its isolation into an independent institution of democracy, in this connection, the author sets the goal of a comparative study of the legal nature of the all-Russian vote as a novel of 2020. Methods: the methodological framework for the study is a set of methods of scientific knowledge, among which the main ones are the comparative legal and formal legal methods. Results: the author's position grounded in the work is based on the legislation, judicial and law enforcement practice, scientific works in the field of institutions of democracy. On the basis of the conducted analysis, the distinctive parameters of the all-Russian voting, its special legal nature are revealed, and the question of the further legal fate of the new type of voting is raised. Conclusions: as a result of the conducted research, the all-Russian voting is separated from the institutions of direct democracy. The criteria of such separation include: the legal nature; the source of the legal regulation; the essence of a ballot question; the initiator; the procedure; the recognition of the vote as valid. Based on the specified criteria, the all-Russian vote is defined as an independent institution of democracy. It is established that its further existence depends on the constitutionally verified legislative support and the scope of the constitutional reform.
\end{abstract}

Key words: the all-Russian vote, referendum, popular vote, constitutional amendment, democracy.

Citation. Slobodchikova S.N. The Constitutional Problems of the All-Russian Vote. Legal Concept $=$ Pravovaya paradigma, 2021, vol. 20, no. 1, pp. 68-72. (in Russian). DOI: https://doi.org/10.15688/lc.jvolsu.2021.1.10

УДК 342.8

ББК 67.400 .8
Дата поступления статьи: 16.01.2021

Дата принятия статьи: 09.02.2021

\section{КОНСТИТУЦИОННАЯ ПРОБЛЕМАТИКА ОБЩЕРОССИЙСКОГО ГОЛОСОВАНИЯ}

\author{
Светлана Николаевна Слободчикова \\ Байкальский государственный университет, г. Иркутск, Российская Федерация
}

Введение: композиционная трансформация отечественного правового пространства требует придания четких форм новым конституционно-правовым феноменам. Сравнение общероссийского голосования с существующими институтами непосредственной демократии способствует его обособлению в самостоятельный институт народовластия, в связи с чем автором поставлена цель компаративного исследования правовой природы общероссийского голосования как новеллы 2020 года. Методы: методологическую основу данного исследования составляет совокупность методов научного познания, среди которых основное место занимают сравнительно-правовой и формально-юридический методы. Результаты: обоснованная в работе авторская позиция опирается на законодательство, судебную и правоприменительную практику, научные труды в области институтов народовластия. На основе проведенного анализа выявляются отличительные параметры общероссийского голосования, его особая юридическая природа, ставится вопрос о дальнейшей правовой судьбе нового вида голосования. Выводы: в результате проведенного исследования выявлено, что общероссийское голосование обособлено от институтов прямой демократии. К критериям такого обособления автор относит: правовую природу, источник правового регулирования, сущность выносимого на голосование вопроса, инициатора проведения, порядок проведения, признание голосования состояв- 
шимся. На основе заданных критериев общероссийское голосование определяется как самостоятельный институт народовластия. Устанавливается, что дальнейшее его существование зависит от конституционно выверенного законодательного обеспечения и масштабов конституционной реформы.

Ключевые слова: общероссийское голосование, референдум, всенародное голосование, конституционная поправка, народовластие.

Цитирование. Слободчикова С. Н. Конституционная проблематика общероссийского голосования // Legal Concept $=$ Правовая парадигма. - 2021. - T. 20, № 1. - C. 68-72. - DOI: https://doi.org/10.15688/lc.jvolsu.2021.1.10

\section{Введение}

Формирование демократического государства невозможно без развития и совершенствования форм народного волеизъявления. В Российской Федерации именно народ, принимая Конституцию 1993 г., большинством голосов утвердил фундаментальные основы развития государства, положение личности и общества в нем. Однако конституционное развитие есть процесс динамичный и влекущий необходимость корректив в социальных и политических отношениях [6, с. $146 ; 7$, с. 59]. 2020 год показал, что Конституция Российской Федерации, как развивающаяся правовая материя, может поддаваться давлению жизни и изменяться, когда этого требуют сложившиеся обстоятельства $[4$, с. $821 ; 5$, с. $55 ; 8$, c. 178]. Вместе с тем конституционная трансформация затронула и сам механизм принятия поправок к некоторым главам Основного закона в фокусе появления нового демократического института - общероссийского голосования.

Потребность в теоретической разработке проблематики общероссийского голосования обусловлена рядом причин. Во-первых, до начала 2020 г. рассматриваемое правовое явление не было известно российскому конституционному праву. В связи с этим в науке практически отсутствуют взгляды относительно юридической природы общероссийского голосования, а также перспектив его правовой судьбы (см. также: [2]). Во-вторых, в настоящее время научным сообществом еще не сформировано целостное представление о месте и роли общероссийского голосования в системе существующих институтов народовластия. Вместе с тем возникает вопрос о необходимости и целесообразности внедрения общероссийского голосования на постоянной основе как в отечественную кон- ституционно-правовую модель народовластия, так и в механизм принятия конституционной поправки. Полагаем, данный вопрос в реалиях современной действительности стоит и перед законодателем, и перед всем научным сообществом и требует качественного сущностного осмысления и конституционно выверенного подхода.

\section{Компаративное исследование правовой природы общероссийского голосования}

Конституционный суд Российской Федерации, исследуя в своем заключении от 16 марта 2020 г. вопрос о соответствии Конституции РФ порядка вступления в силу поправки 2020 г., указал на особую юридическую природу общероссийского голосования ${ }^{1}$. Представляется, что общероссийское голосование - это конституционная новелла 2020 г., которую следует отличать от иных институтов народовластия по некоторым ключевым параметрам.

Источник правового регулирования. Процедура организации и проведения общероссийского голосования регламентировалась Законом Российской Федерации о поправке к Конституции Российской Федерации от 14 марта 2020 г. № 1-ФКЗ «О совершенствовании регулирования отдельных вопросов организации и функционирования публичной власти» ${ }^{2}$ (далее - Закон РФ о поправке 2020 г.), а также правовыми актами Президента Российской Федерации и ЦИК России (см. также: [1; 3]). Подобный порядок организации и проведения общероссийского голосования является уникальным, учитывает сложную эпидемиологическую обстановку и опирается на опыт зарубежных государств (к примеру, парламентские выборы в Национальное собрание Республики Корея в апреле 2020 г.) в поиске ба- 


\section{ТЕОРИЯ И ПРАКТИКА ГОСУДАРСТВЕННО-ПРАВОВОГО РАЗВИТИЯ}

ланса между обеспечением санитарно-эпидемиологического благополучия населения и реализаций права на одобрение конституционных изменений. Вместе с тем дальнейшая правовая судьба нового демократического института не определена. Если общероссийское голосование станет содержательной константой механизма принятия конституционных поправок, то его либо придется включать в федеральное конституционное законодательство о референдуме РФ, расширяя круг вопросов, которые могут выноситься на референдум, либо, что, полагаем, предпочтительнее, вносить изменения в действующее рамочное федеральное законодательство в области выборов и референдумов.

Сущность выносимого на голосование вопроса. Предметный вопрос общероссийского голосования заключался не в принятии населением общезначимого решения, а в одобрении нового концепта развития конституционного государства, предложенного главой государства, принятого уполномоченными органами государственной власти и не выходящего за текстуальные рамки действующего Основного закона. Подобный конструкт отличает общероссийское голосование, вопервых, от федерального референдума, на котором принимаются вопросы государственного значения; во-вторых, от всенародного голосования, на которое может быть вынесен проект новой Конституции РФ.

Инициатор проведения. Президент РФ как инициатор проведения общероссийского голосования - уникальная организационная особенность общероссийского голосования. Следует отметить, что до 2020 г. главе государства отводилась роль назначающего голосование, а не инициатора. Так, стадии назначения Президентом РФ федерального референдума предшествует стадия создания и регистрации инициативной группы граждан по его проведению, включающая сбор подписей в поддержку такой инициативы и проверку Конституционным судом РФ соответствия Основному закону инициативы проведения федерального референдума по предложенному вопросу. В свою очередь, назначение и проведение общероссийского голосования как инициативы главы государства стало возможным после дачи положи- тельного заключения высшего судебного органа конституционного контроля РФ.

Порядок проведения. Общероссийскому голосованию присущ некоторый спектр особенностей в этой части. Данный вид голосования (в отличие от выборов, референдума любого уровня, всенародного голосования, отзыва избирателями) можно назначить не только на воскресенье, но и на любой другой день недели (например, на среду), который объявляется нерабочим. Вместе с тем подобный вид голосования может быть объектом лотерей и викторин с целью привлечения народного внимания и стимулирования к участию в нем. Еще одна особенность - эксклюзивное право общественных палат, а не политических партий и иных общественных объединений назначать наблюдателей за проведением голосования.

Признание голосования состоявшимся. Современные институты непосредственной демократии стандартизированы [9, c. $16 ; 10$, с. 309]. Ключевой константой многих видов голосования является количество участников, необходимое для признания голосования состоявшимся. К примеру, и федеральный референдум, и всенародное голосование признаются состоявшимся, только если в голосовании приняло участие более половины всех участников, включенных в списки. В свою очередь, в Законе РФ о поправке 2020 г. количество участников общероссийского голосования, необходимое для признания такого голосования состоявшимся, не устанавливается. Полагаем, соблюдение обозначенной константы является обязательной для общероссийского голосования, скрепляющего общественный договор о будущем конституционного государства. В случае имплементации общероссийского голосования в область правового регулирования референдумов подобную константу следует включить в содержательное наполнение исследуемого явления.

\section{Выводы}

Компаративное исследование правовой природы общероссийского голосования позволяет определить его особую юридическую природу, отличную от природы существующих форм народовластия, и выделить отличитель- 
ные черты общероссийского голосования как самостоятельного правового института в отечественной конституционно-правовой модели народовластия.

Во-первых, общероссийское голосование является институтом народного одобрения (а не принятия) государственных решений. Подобная модель общественного договора «государство-инициатор - народлегитиматор» кардинально отличается от уже известной классической модели референдума «народ-инициатор - государство как посредник в реализации».

Во-вторых, общероссийское голосование - это заключительный элемент в многоуровневом механизме утверждения конституичионных поправок. Однако вопрос о внедрении подобного элемента в обозначенный механизм на постоянной основе, полагаем, требует конституционно выверенного подхода, учитывающего масштаб конституционных изменений.

\section{ПРИМЕЧАНИЯ}

${ }^{1}$ О соответствии положениям глав 1, 2 и 9 Конституции Российской Федерации не вступивших в силу положений Закона Российской Федерации о поправке к Конституции Российской Федерации «О совершенствовании регулирования отдельных вопросов организации и функционирования публичной власти», а также о соответствии Конституции Российской Федерации порядка вступления в силу ст. 1 данного Закона в связи с запросом Президента Российской Федерации : Заключение Конституционного Суда Российской Федерации от 16 марта 2020 г. № 1-3 // Российская газета. 2020. 17 марта.

${ }^{2}$ См.: Собрание законодательства РФ. 2020. № 11. Ст. 1416.

\section{СПИСОК ЛИТЕРАТУРЫ}

1. Авакьян, С. А. Проекты законов о поправках к Конституции Российской Федерации: грядет раунд четвертый? / С. А. Авакьян // Конституционное и муниципальное право. - 2020. - № 1. - С. 31-44.

2. Коновалов, Д. Д. Общероссийское голосование по вопросу одобрения изменений в Конституцию России: зачем и почему? / Д. Д. Коновалов // Конституционное и муниципальное право. 2020. - № 11. - C. 60-63.
3. Хабриева, Т. Я. Тематический комментарий к Закону Российской Федерации о поправке к Конституции Российской Федерации от 14 марта 2020 года № 1-ФКЗ «О совершенствовании регулирования отдельных вопросов организации и функционирования публичной власти» / Т. Я. Хабриева, А. А. Клишас. - М. : Инфра-М, 2020. - 240 с.

4. Хабриева, Т. Я. Парадигмы конституционной реформы / Т. Я. Хабриева // Журнал зарубежного законодательства и сравнительного правоведения. - 2015. - № 5 (54). - С. 820-830.

5. Чуксина, В. В. Глобализация, права человека и обязанности государства / В. В. Чуксина // Известия Иркутской государственной экономической академии (Байкальский государственный университет экономики и права). -2010. - № 6.

6. Чуксина, В. В. Новые вызовы демократии и национальной безопасности государств в изменяющемся мире / В. В. Чуксина, О.В.Бондаренко // Правовые средства обеспечения национальной безопасности Российской Федерации: история и современность : сб. тр. материалов Междунар. науч.-практ. конф. - Иркутск : Изд-во БГУ, 2020. - С. 146-150.

7. Эбзеев, Б. С. Конституционное право России : учебник / Б. С. Эбзеев. - М. : Проспект, 2019. - $768 \mathrm{c}$.

8. Якимова, Е. М. Публичные услуги через призму поправок в Конституцию России и распространения коронавирусной инфекции / Е. М. Якимова, И. А. Пуляевская // Правовые средства обеспечения национальной безопасности Российской Федерации: история и современность : сб. тр. материалов Междунар. науч.-практ. конф. - Иркутск : Изд-во БГУ, 2020. - С. 178-180.

9. Якимова, Е. М. Информационное обеспечение избирательного (референдумного) процесса как средство реализации принципа свободных выборов: истоки правового регулирования и современное состояние российского законодательства / Е. М. Якимова // Legal Concept = Правовая парадигма. -2018. - Т. 17, № 4. - C. 16-21. - DOI: https:/ /doi.org/10.15688/lc.jvolsu.2018.4.2.

10. Якимова, Е. М. Свободные выборы как международный избирательный стандарт / Е. М. Якимова // Евразийский интеграционный проект: цивилизационная идентичность и глобальное позиционирование : сб. тр. материалов Междунар. Байкальского форума. - Иркутск : Изд-во БГУ, 2018. - С. 309-311.

\section{REFERENCES}

1. Avak'yan S.A. Proyekty zakonov o popravkakh k Konstitutsii Rossiyskoy Federatsii: gryadet raund chetvertyy? [Draft of laws on amendments to the Constitution of the Russian Federation: is round four 
coming?]. Konstitutsionnoye i munitsipal'noye pravo, 2020, no. 1, pp. 31-44.

2. Konovalov D.D. Obshcherossiyskoye golosovaniye po voprosu odobreniya izmeneniy v Konstitutsiyu Rossii: zachem i pochemu? [The AllRussian voting on the approval of amendments to the Russian Constitution: why and what for?]. Konstitutsionnoye $i$ munitsipal'noye pravo, 2020, no. 11 , pp. $60-63$.

3. Khabriyeva T.Y., Klishas A.A. Tematicheskiy kommentariy $k$ Zakonu Rossiyskoy Federatsii o popravke $k$ Konstitutsii Rossiyskoy Federatsii ot 14 marta 2020 goda № 1-FKZ «O sovershenstvovanii regulirovaniya otdel'nykh voprosov organizatsii $i$ funktsionirovaniya publichnoy vlasti» [Thematic commentary to the Law of the Russian Federation on the amendment to the Constitution of the Russian Federation of March 14, 2020 N. 1-FKZ “On improving the regulation of certain issues of the organization and functioning of public authorities"]. Moscow, Infra-M Publ., 2020.240 p.

4. Khabriyeva T.Y. Paradigmy konstitutsionnoy reform [Paradigms of constitutional reform]. Zhurnal zarubezhnogo zakonodatel'stva i sravnitel'nogo pravovedeniya, 2015, no. 5 (54), pp. 820-830.

5. Chuksina V.V. Globalizatsiya, prava cheloveka i obyazannosti gosudarstva [Globalization, human rights and state responsibilities]. Izvestiya Irkutskoy gosudarstvennoy ekonomicheskoy akademii (Baykal'skiy gosudarstvennyy universitet ekonomiki i prava), 2010, no. 6.

6. Chuksina V.V., Bondarenko O.V. Novyye vyzovy demokratii i natsional'noy bezopasnosti gosudarstv $\mathrm{v}$ izmenyayushchemsya mire [New challenges to democracy and national security of states in a changing world]. Pravovyye sredstva obespecheniya natsional'noy bezopasnosti Rossiyskoy Federatsii: istoriya i sovremennost'. Sbornik trudov materialov Mezhdunar. nauch.-prakt. konf. [Legal Means of Ensuring the National Security of the Russian Federation: History and Modernity. Collection of Proceedings of Materials of the
International Research and Practice Conference]. Irkutsk, Izd-vo BGU, 2020, pp. 146-150.

7. Ebzeev B.S. Konstitutsionnoye pravo Rossii: uchebnik [Constitutional law of Russia: textbook]. Moscow, Prospect Publ., 2019. 768 p.

8. Yakimova E.M., Pulyaevskaya I.A. Publichnyye uslugi cherez prizmu popravok $\mathrm{V}$ Konstitutsiyu Rossii i rasprostraneniya koronavirusnoy infektsii [Public services through the prism of amendments to the Constitution of Russia and the spread of coronavirus infection]. Pravovyye sredstva obespecheniya natsional'noy bezopasnosti Rossiyskoy Federatsii: istoriya i sovremennost'. Sbornik trudov materialov mezhdunar. nauchnoprakt. konf. [Legal Means of Ensuring the National Security of the Russian Federation: History and Modernity. Collection of Proceedings of Materials of the International Research and Practice Conference]. Irkutsk, Izd-vo BGU, 2020, pp. 178-180.

9. Yakimova E.M. Informatsionnoye obespecheniye izbiratel'nogo (referendumnogo) protsessa kak sredstvo realizatsii printsipa svobodnykh vyborov: istoki pravovogo regulirovaniya i sovremennoye sostoyaniye rossiyskogo zakonodatel'stva [The information support of the election (referendum) process as a means of implementing the principle of free elections: the origins of the legal regulation and modern state of the russian legislation]. Legal Concept = Pravovaya paradigma, 2018, vol. 17, no. 4, pp. 16-21. DOI: https://doi.org/ 10.15688/lc.jvolsu.2018.4.2.

10. Yakimova E.M. Svobodnye vybory kak mezhdunarodnyj izbiratel'nyj standart [The free elections principle as one of the international electoral standards]. Evrazijskij integracionnyj proekt: civilizacionnaya identichnost' $i$ global'noe pozicionirovanie. Sbornik trudov materialov Mezhdunar. Bajkal skogo foruma [Eurasian Integration Project: Civilizational Identity and Global Positioning. Collection of Proceedings of Materials of the International Baikal Forum]. Irkutsk, Izd-vo BGU, 2018, pp. 309-311.

\section{Information About the Author}

Svetlana N. Slobodchikova, Candidate of Sciences (Jurisprudence), Associate Professor, Department of State and Legal Disciplines, Baikal State University, Lenina St, 11, 664003 Irkutsk, Russian Federation, sveta150189@gmail.com, https://orcid.org/0000-0002-3638-3416

\section{Информация об авторе}

Светлана Николаевна Слободчикова, кандидат юридических наук, доцент кафедры государственно-правовых дисциплин, Байкальский государственный университет, ул. Ленина, 11, 664003 г. Иркутск, Российская Федерация, sveta150189@gmail.com, https://orcid.org/0000-0002-3638-3416 